\title{
Reward strategy and practice as a tool to retain employees: case of Croatia
}

\author{
Lovorka Galetić \\ University of Zagreb, Faculty of Economics \& Business, Zagreb, Croatia
}

\begin{abstract}
This paper explores the differences in reward strategy and practice between Croatia and EU countries. Reward is one of the key tools for attracting, retaining and motivating employees. Croatian and European companies have already started competing for the best human resources and the figures for 2016 reveal that Croatia is currently experiencing negative net migration rates (Croatian Bureau of Statistics, 2019). Since the trend is discouraging for Croatian companies, we find it necessary to examine the state of reward strategy and practice in Croatia. Our empirical research was conducted on a sample of 61 middle- and large-sized Croatian companies. Research results revealed that there is a very large gap between the annual earnings of Croatian employees and average annual earnings in EU companies. However, the differences in incentive pay practices, benefits and non-monetary incentives between Croatia and other countries were not so great.
\end{abstract}

\section{Keywords}

reward strategy, reward management, Croatia, EU countries

\section{Introduction}

Reward is a key element of the employment relationship and, in addition to being the single greatest operating cost for many organizations, it has been advocated as a tool for attracting, retaining and motivating employees. The high impact of reward management on overall organizational performance and competitiveness (Stajkovic \& Luthans, 2001; Hansen, 1997, Jenkins et al. 1998) prompted us to research reward management in detail within Croatian companies. Furthermore, since Croatia entered the European Union (EU), Croatian companies are part of the larger EU labour market where mobility and free movement of persons is guaranteed. In such a context, reward management strategies and practices used by Croatian companies need to be competitive within the larger EU context. The basic EU principle of mobility and free movement implies that all countries and companies have access to candidates from the common labour market (European Commission, 2014). The competition for the best human resources among
Croatian and European companies has already started and the data for 2018 (Croatian Bureau of Statistics, 2019) testify to a negative net migration with other countries. This is discouraging for Croatian companies and the reasons for this worrying trend may be found in the state of strategy and practice of reward management in Croatia.

The purpose of this paper is to identify reward strategies that would allow Croatian companies to increase their relative competitiveness in the EU labour market and reduce excessive employee drain. To gain a better insight into the compensation strategies and practices used by Croatian companies we conducted an empirical research and obtained answers to the following research questions:

RQ1: What types of individual and group incentives as well as non-mandatory benefits are offered in Croatian enterprises, and does context matter?

RQ2: What is the difference between compensation strategy and practice in Croatian and EU enterprises?

RQ3: What improvements would make 
compensation strategy and practice of Croatian enterprises more attractive to young people who are leaving Croatia?

\section{Theoretical background}

Employee performance and rewards should be managed in a strategic way, which means that organisations need to identify and apply reward principles, policies and practices that best support the strategic objectives of the organisation as a whole and human resource management specifically. Reward strategy can be defined as a declaration of intent which explains what an organization wants to do in the future to develop and implement reward policies, practices and processes which will further the achievement of its business goals and meet the needs of its stakeholders (Armstrong, 2012). Although it is often seen as nothing more than a process of defining broad plans for the future, reward strategy is very much concerned with the design of the reward system. Namely, if managers want to implement a reward strategy, they must design a reward system which will allow them to translate the strategy into action and choose the appropriate techniques to fit the strategy.

Milkovich et al. (2014) argue that all organizations that pay people have a reward strategy, only some of them may have written their reward strategy for all to see and understand while other organizations may not even realize that they have a reward strategy at all. In the latter case, managers make strategic reward decisions more chaotically, as ad hoc responses to pressures from the economic, socio-political and regulatory context in which their enterprises operate. It means that different organizations have different reward strategies. However, Armstrong and Stephens (2012) emphasize that strategies adopted by different organizations will include similar aspects of reward, but their treatment will vary as a result of the differences in business contexts, strategies and cultures.

These similar aspects of reward that are implemented differently in different organizations are the basis of the reward system. Managers are free to choose from multiple compensation policies to achieve the desired effects on employee behaviours and performance of their organizations. Various organizations typically use the following main reward components: base pay, individual variable pay or individual incentives, group incentives, employee benefits and non-financial rewards (Galetić, 2015).
Base pay is a fixed amount of money (salary or wage) paid to an employee in return for efforts and time spent on the job. Also defined as the rate for the job, base pay is the primary component of total remuneration, and can be defined as the part of an employee's direct remuneration that is not performance-related (Shields, 2008). Base pay amounts for different jobs are usually determined according to the required level of skill, effort, responsibility and working conditions. These compensable factors influence pay level (Martocchio, 2004). Organisations conduct market rate analyses to identify base pay rates in the external market and to compare their salaries with those of competitors. Market rate analysis also enables organizations to decide on their preferred labour market position (Bashkir, 2013). Namely, different employers set different pay levels and choose to pay above or below what others are paying for the same work (Milkovich et al., 2014). Having at their disposal both the internal and external pay data, managers can design the pay structure that will attract and retain the right employees.

Individual variable pay or individual incentives can take a wide variety of forms. These may include additional amounts provided weekly, monthly, quarterly or annually as well as amounts granted upon the achievement of a certain result or occurrence of a certain event. Individual incentives range from premium and differential payments for employees who work in unusual situations to bonuses for individual innovation and creativity or to awards and bonuses for achieving all kinds of desired results (Henderson, 2006). It has been wellestablished in the literature that individual-based bonus schemes, such as individual-based pay for performance, merit pay, sales commission incentives and piece-rates, can have a positive effect on job satisfaction (Green \& Heywood, 2008; Jovanović, 2019), productivity (Cadsby, Song \& Tapon, 2007), and level of organizational performance (Dohmen \& Falk, 2011). Furthermore, some forms of individual incentive pay reduce employee turnover (O'Halloran, 2011) and play an important role in motivating staff to achieve organizational goals (Schraeder \& Becton, 2003).

The usual types of group incentives discussed in the literature are team pay, gain-sharing, profitsharing, employee-shared ownership (mostly in the form of ESOP) and stock options. The literature recognizes a series of possibly beneficial effects of group incentives: increase in employees' 
commitment to the organization, higher task motivation, higher interest in the affairs of the organization, reduced absenteeism and turnover, increased identification with and understanding of the organization, development of cooperation and information sharing among employees, improvement of labour-management relations and reduced industrial conflicts (Shields, 2016; Armstrong, 2015). It seems that the future of group incentives is assured. Given that work is becoming increasingly interdependent, and that the need for cooperation grows, we may expect to see an increase in the number of incentive plans that foster group cohesion and collective effort (Shields, 2016).

Employee benefits are part of the tangible reward package offered by an employer to its employees (Renaud \& Morrin, 2015). They are the costly part of the remuneration package because they can amount to a third or more of an organisation's basic pay costs. Employee benefits provide for the personal needs of employees while increasing their commitment to the organization (Armstrong, 2015). In labour markets where key talents are in short supply, financial and nonfinancial benefits increasingly contribute to the ability of the reward management system to attract, retain and motivate high-potential and highperforming employees (Shields, 2016).

Non-financial rewards focus on the needs of employees for varying degrees of recognition, achievement, responsibility, autonomy, influence and personal growth. They can be extrinsic, such as recognition, or intrinsic, i.e. arising from the work itself and associated with job challenge and interest (Armstrong, 2015). Henderson (2006) argues that any activity that has an impact on the intellectual, emotional and physical well-being of the employee and is not specifically covered by the financial rewards is part of the non-financial reward system. Furthermore, over the last 50 years, behavioural scientists have been describing nonfinancial rewards as critical for improving workplace performance.

Top managers are required to provide guidelines on development and implementation of an attractive pay structure taking into consideration all of the above-mentioned aspects of compensation strategy. Not an easy task since reward policy decisions include a number of specific considerations: how much money needs to be reserved for the whole compensation package, should the structure of pay lead the market, what are the minimum and maximum levels of pay, how should the general relationship among pay levels be defined, what portion of total compensation should go to base pay, variable pay, group incentives (if any) and benefits, what performance standards should be used at different organizational levels and so on. Only the right decisions can produce a comprehensive reward system which is able to attract, retain and motivate employees.

\section{Research methodology}

Sample. The first step in designing our research was to select participants for our empirical research study. This research study is part of a larger project funded by the Croatian Science Foundation aiming to cover the entire population of Croatian companies and emphasis was placed on large and medium-sized companies since they are expected to generally have more sophisticated HRM practices (Kotey \& Sheridan 2004), reward practices included. The population of Croatian companies (excluding banking and finance sector) that employ more than 100 staff was obtained through the Croatian Chamber of Commerce (CCC). As per this source, approximately 1700 companies in Croatia employ more than 100 staff, out of which 386 companies employ more than 250 staff (labelled as "large companies").

Research instrument. A questionnaire that was designed for the purpose of conducting empirical research consisted of 46 questions in total. The majority of the questions were closed-ended and referred to different pay modalities as well as various attitudes, behaviour-based indicators or organizational outcomes that were of interest as potential independent variables. A certain number of variables were treated as dummy variables (e.g. whether certain pay element existed in organization or not), while the majority was of nominal and continuous character. The respondents were asked to make an assessment by using a Likert-type 5-point scale ( $1=$ not important at all, $5=$ of utmost importance). The majority of key questions about different reward management strategies were taken or adapted from different journal articles and the internal materials of the Chartered Institute for Personnel Development.

Data collection and analysis. After the population was identified, a questionnaire was created using online resources and an e-mail with a cover letter from the Project leader was sent to HRM departments of all companies in the CCC database in April 2017. By the end of November 2017, we received 61 fulfilled questionnaires 
representing approximately $3.59 \%$ of the determined population size.

Company characteristics in the sample are given in a summary table below.

Table 1 Data distribution by sample characteristics

\begin{tabular}{|c|c|}
\hline $\begin{array}{l}\text { Company } \\
\text { characteristic }\end{array}$ & Data distribution \\
\hline Industry & $\begin{array}{l}\text { Manufacturing }-42.6 \% \\
\text { Services }-57.4 \%\end{array}$ \\
\hline $\begin{array}{ll}\text { Year } & \text { of } \\
\text { establishment }\end{array}$ & $\begin{array}{l}\text { Before } 1990-47.50 \% \\
\text { After } 1990-52.50 \%\end{array}$ \\
\hline $\begin{array}{l}\text { Number of } \\
\text { employees }\end{array}$ & $\begin{array}{l}\text { Less than } 250-52.50 \% \\
\text { More than } 250-47.50 \%\end{array}$ \\
\hline $\begin{array}{l}\text { Ownership } \\
\text { structure }\end{array}$ & $\begin{array}{l}\text { Private domestic }-55.70 \% \\
\text { Private foreign }-32.80 \% \\
\text { State-owned and mixed }-11.50 \%\end{array}$ \\
\hline Legal form & $\begin{array}{l}\text { Joint stock company }-32.80 \% \\
\text { Limited liability company }-67.20 \%\end{array}$ \\
\hline $\begin{array}{l}\text { Profitability in the } \\
\text { last } 5 \text { years }\end{array}$ & $\begin{array}{l}\text { Cannot assess }-1.3 \% \\
\text { Unprofitable or low profitability }-26.3 \% \\
\text { Profitable }-72.10 \%\end{array}$ \\
\hline
\end{tabular}

As it can be seen from Table 1, our sample included both manufacturing and service companies $(\mathrm{N}=26$ and $\mathrm{N}=35$, respectively), companies that employ less than $250(52.5 \%)$ and more than 250 people $(47.5 \%)$, as well those founded after $(52.5 \%)$ and before the dissolution of the Yugoslavia (47.5\%) in 1990. When it comes to ownership structure, more than half of the sample is comprised of private domestic companies, approximately one-third of the sample are privately-owned foreign companies, while stateowned and companies with mixed ownership are underrepresented in the sample (11.5\% combined). Limited liability companies form the majority in the sample $(67.20 \%)$ while the rest of the companies in the sample are joint stock companies $(32.8 \%)$. When it comes to self-reported profitability in the last 5 years, $72.1 \%$ of the companies reported being profitable, approximately one quarter of them had low profitability or were unprofitable.

\section{Research results}

In today's challenging business environment, the need to use pay strategically is more important than ever as organizations and their leaders look for ways to improve outcomes, performance, productivity, and teamwork (Gross \& Friedman, 2004). Therefore, the first step in analysing the data was to explore the prevalence of formally designed reward strategies and reward policies in the sampled companies as well as their contribution to competitive advantage. The results are shown in Table 2.

Table 2 Formally designed reward strategies and reward policies and their contribution to competitive advantage

\begin{tabular}{l|l}
\hline $\begin{array}{l}\text { Pay strategy } \\
\text { element }\end{array}$ & Data distribution \\
\hline $\begin{array}{l}\text { Formally designed } \\
\text { reward strategy }\end{array}$ & $\begin{array}{l}\text { Does not exist - 20.00\% } \\
\text { Partially exists - 30.00\% } \\
\text { Formally exists - 50.00\% }\end{array}$ \\
\hline $\begin{array}{l}\text { Formally designed } \\
\text { reward policy }\end{array}$ & $\begin{array}{l}\text { Does not exist - 8.17\% } \\
\text { Partially exists - 39.34\% } \\
\text { Formally exists - 52.46\% }\end{array}$ \\
\hline $\begin{array}{l}\text { Contribution } \\
\text { reward system to } \\
\text { competitive }\end{array}$ & Does not contribute at all - $3.28 \%$ \\
advantage & Contributes minimally - 21.31\% \\
& Contributes partially - 34.43\% \\
\hline
\end{tabular}

Source: The author

In one half of the sampled companies a reward strategy exists on a formal level, while in the other half it either exists only partially, or not at all. As regards reward policies, the results are quite similar; however, formally designed policies are more prevalent than formally designed reward strategies. HR managers were asked to assess the extent to which the reward system contributes to the competitive advantage of the company and the analysis revealed that in almost $45 \%$ of cases the reward system contributed in large part or exceptionally, while in an additional one third of cases the contribution was partial. Next, we wanted to learn about the most important goals that the employers want to achieve by implementing a reward strategy. Consequently, the respondents were asked to make an assessment on a Likert-type 5 -point scale $(1=$ not important at all, $5=$ of utmost importance). 


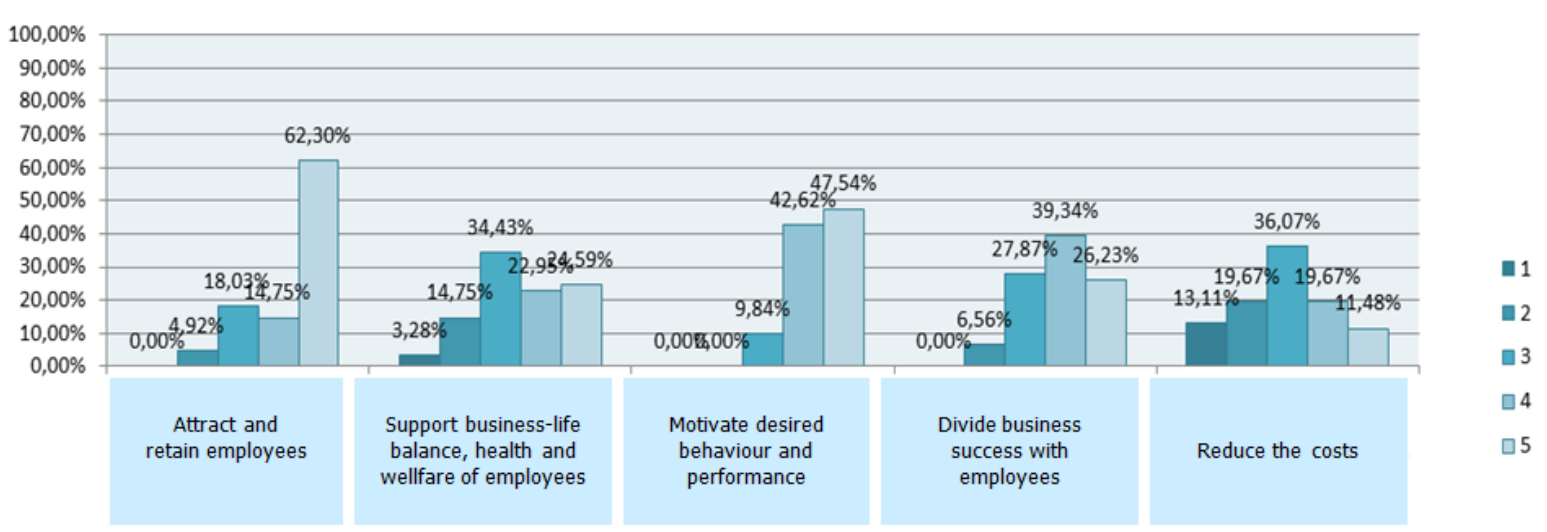

Figure 1 The goals that the employers want to achieve by implementing a reward system Source: The author

Employers primarily wish to attract and retain efficient employees as well as to motivate and stimulate desired behaviour. It is interesting to note that cost reduction is a very or most important goal for only $31.15 \%$ of employers while $65.57 \%$ of them want to share business success with their employees. The promotion of work-life balance is a very or extremely important goal for $47.5 \%$ of employers, which demonstrates that many of them have a good understanding of the wishes and needs of the young generation (generation Y).

Many of the above-mentioned goals can be achieved much more easily if variable pay is a part of reward strategy. As variable or incentive pay related to the performance of an individual, a team or organization as a whole is in increasing use nowadays, we were curious to see how many Croatian enterprises reward their employees using individual and group incentive pay. As we can see from Table 3, individual incentives are rather popular in Croatian enterprises. The most frequent type of individual incentives applied is performance appraisal, taken on average by $50 \%$ for all categories of employees.

Table 3 The use of individual incentive pay in Croatian enterprises with regard to different employee categories

\begin{tabular}{l|c|c|c}
\hline \multirow{2}{*}{$\begin{array}{l}\text { Type of individual } \\
\text { incentive }\end{array}$} & \multicolumn{3}{|c}{$\begin{array}{c}\% \text { of enterprises applying for } \\
\text { different categories of } \\
\text { employees }\end{array}$} \\
\cline { 2 - 4 } & Managers & Experts & Other \\
\hline Norm measurement & 0.00 & 5.40 & 10.70 \\
\hline Performance appraisal & 53.60 & 50.00 & 48.20 \\
\hline Occasional bonuses & 44.60 & 30.40 & 23.20 \\
\hline Sales commission & 21.40 & 17.90 & 17.90 \\
\hline $\begin{array}{l}\text { Ind. non-financial } \\
\text { recognition }\end{array}$ & 37.50 & 21.40 & 16.10 \\
\hline None of the above & 14.30 & 28.60 & 32.10 \\
\hline $\begin{array}{l}\text { Individual performance } \\
\text { appraisal in general }\end{array}$ & \multicolumn{3}{|c}{75.00} \\
\hline
\end{tabular}

Source: The author
Occasional bonuses based on the evaluation by a direct superior are most frequently used for managers $(44.60 \%)$, somewhat less frequently for experts $(30.40 \%)$ and the least frequently for other employees (23.20\%). Individual non-financial recognition is mostly applied for managers $(37.50 \%)$ and surprisingly rarely for other employees $(16.10 \%)$. Norm measurement is only sporadically used, mostly for other employees $(10.70 \%)$, while for many other employees $(32.10 \%)$ and experts $(28.60 \%)$ individual incentives are not applied at all. Since performance appraisal is the most frequently used tool for evaluating employees' individual performance, it should be emphasised that $75 \%$ of Croatian enterprises use this type of incentive for at least one category of employees.

Table 4 The use of group incentives in Croatian enterprises with regard to different employee categories

\begin{tabular}{l|c|c|c}
\hline \multirow{2}{*}{$\begin{array}{l}\text { Type of group } \\
\text { incentive }\end{array}$} & \multicolumn{3}{|c}{$\begin{array}{c}\text { \% of enterprises applying for } \\
\text { different categories of employees }\end{array}$} \\
\cline { 2 - 4 } & $\begin{array}{c}\text { Manag } \\
\text { ers }\end{array}$ & Experts & Other \\
\hline Gain-sharing & 7.1 & 5.40 & 3.60 \\
\hline Profit-sharing & 21.40 & 8.90 & 7.10 \\
\hline ESOP & 5.40 & 5.40 & 7.10 \\
\hline Share options & 7.10 & 1.80 & 1.80 \\
\hline $\begin{array}{l}\text { Non-financial group } \\
\text { recognition }\end{array}$ & 25.00 & 28.60 & 32.10 \\
\hline \multicolumn{3}{c}{\begin{tabular}{l} 
Financial participation applied in general \\
(for at least one category of employees): \\
\hline
\end{tabular}} & 37.70 \\
\hline
\end{tabular}


Group incentives (Table 4) are not as popular in Croatian enterprises as individual incentives. The most frequently applied group incentive is profitsharing, which is used in $21.4 \%$ enterprises for managers, $8.9 \%$ enterprises for experts and only in $7.1 \%$ enterprises for other employees. Other cash group incentives are applied less frequently than profit sharing or they are not applied at all. $44.6 \%$ of enterprises do not use any of the above group incentives for experts. $41.1 \%$ do not use them for other employees and, surprisingly, $37.5 \%$ of enterprises do not use any financial group incentives for managers. On the other hand, nonfinancial group recognition is very popular for all categories of employees and it is used in $25 \%$ of cases for managers, $28.6 \%$ of cases for experts and $32.1 \%$ for other employees.

Next we were interested in the presence of different types of non-mandatory benefits in the sampled enterprises. We analysed the data according to the availability of benefits to all employees or only certain groups based on seniority, education level, position etc. Results are shown in Table 5.

As it can be seen from Table 5, the most frequently offered benefits to all employees are paid commuting expenses, in as many as $95.5 \%$ of cases. Benefits that are available quite often (in $50.0 \%$ to $56.8 \%$ of the enterprises) to all employees are paid leave above legal days, discounted company products, social activities and education and training. Company car is the privilege for certain groups of employees, mostly managers, in $93.2 \%$ of enterprises. Telephone and paid phone expenses $(65.9 \%)$, paid seminars and conferences $(52.3 \%)$, work from home $(36.4 \%)$ and flexible working hours (34.1\%) are also mostly available to certain groups of employees. Benefits such as recreation and health programmes, loans with favourable interests, paid food expenses, additional health insurance and financial advice, legal and other services are more frequently applied to all employees than to certain groups of employees. All the same, some benefits are really very rare in Croatian enterprises, e.g. elderly care-related benefits, childcare-related benefits, life insurance and additional pension insurance.

Table 5 The availability of different types of benefits in Croatian enterprises

\begin{tabular}{l|c|c|c}
\hline & $\begin{array}{c}\text { Nobody } \\
\text { in the } \\
\text { company }\end{array}$ & $\begin{array}{c}\text { Certain } \\
\text { groups of } \\
\text { employees }\end{array}$ & $\begin{array}{c}\text { Everybody } \\
\text { in the } \\
\text { company }\end{array}$ \\
\hline $\begin{array}{l}\text { Elderly care- } \\
\text { related benefits }\end{array}$ & 97.7 & 0 & 2.3 \\
\hline
\end{tabular}

\begin{tabular}{|c|c|c|c|}
\hline $\begin{array}{l}\text { Childcare- } \\
\text { related benefits }\end{array}$ & 93.2 & 2.3 & 4.5 \\
\hline Life insurance & 70.5 & 18.2 & 11.4 \\
\hline $\begin{array}{l}\text { Additional } \\
\text { pension } \\
\text { insurance }\end{array}$ & 70.5 & 11.4 & 18.2 \\
\hline $\begin{array}{l}\text { Recreation and } \\
\text { health } \\
\text { programs }\end{array}$ & 63.6 & 13.6 & 22.7 \\
\hline $\begin{array}{l}\text { Cultural, sports } \\
\text { and other } \\
\text { events tickets }\end{array}$ & 59.1 & 20.5 & 20.5 \\
\hline $\begin{array}{l}\text { Loans with } \\
\text { favourable } \\
\text { interests }\end{array}$ & 59.1 & 9.1 & 31.8 \\
\hline $\begin{array}{l}\text { Paid food } \\
\text { expenses }\end{array}$ & 56.8 & 9.1 & 34.1 \\
\hline $\begin{array}{l}\text { Additional } \\
\text { health } \\
\text { insurance }\end{array}$ & 54.5 & 18.2 & 27.3 \\
\hline $\begin{array}{l}\text { Financial } \\
\text { advice, legal } \\
\text { and other } \\
\text { services }\end{array}$ & 54.5 & 18.2 & 27.3 \\
\hline $\begin{array}{l}\text { Work from } \\
\text { home }\end{array}$ & 52.3 & 36.4 & 11.4 \\
\hline $\begin{array}{l}\text { Discounted } \\
\text { company } \\
\text { products }\end{array}$ & 40.9 & 6.8 & 52.3 \\
\hline $\begin{array}{l}\text { Flexible } \\
\text { working hours }\end{array}$ & 40.9 & 34.1 & 25 \\
\hline $\begin{array}{l}\text { Paid leave } \\
\text { above legal } \\
\text { days }\end{array}$ & 34.1 & 15.9 & 50 \\
\hline Social activities & 25 & 20.5 & 54.5 \\
\hline $\begin{array}{l}\text { Education and } \\
\text { training }\end{array}$ & 9.1 & 34.1 & 56.8 \\
\hline Company car & 6.8 & 93.2 & 0 \\
\hline $\begin{array}{l}\text { Paid seminars } \\
\text { and } \\
\text { conferences }\end{array}$ & 4.5 & 52.3 & 43.2 \\
\hline $\begin{array}{l}\text { Self-phone and } \\
\text { paid phone } \\
\text { expenses }\end{array}$ & 2.3 & 65.9 & 31.8 \\
\hline $\begin{array}{l}\text { Paid } \\
\text { commuting } \\
\text { expenses }\end{array}$ & 0 & 4.5 & 95.5 \\
\hline
\end{tabular}

When talking about flexible benefits it is important to emphasise that they are also very infrequent in Croatian enterprises. According to the research results, only $11.5 \%$ of sampled enterprises offer their employees some type of a flexible benefits package. At present, employees in $88.5 \%$ of Croatian enterprises are not able to combine benefits according to their needs. However, $27.9 \%$ of the sampled enterprises intend to consider flexible benefits in the future. This is a very important finding because increasing use of 
flexible benefits represents a major trend in human resource management today.

\section{Comparative analysis of reward strategy and practice between Croatia and EU}

The overall level of compensation is an important feature of compensation strategy as well (Gerhart, 2000). A lead pay-level policy maximizes the ability to attract and retain quality employees and minimizes employees' dissatisfaction with pay, while a policy of paying below-market rates may hinder a firm's ability to attract potential employees (Milkovich, Newman, Gerhart, 2014). In different countries compensation levels vary greatly depending on country specific contexts such as national culture, laws, national compensation history, labour unions, market forces or profitability (Martocchio, 2006). Eurostat's Structure of Earnings Survey (SES), which provides comparable data on individual earnings in different EU countries has shown that the average annual earnings in 2014 range from 5,814 EUR in Bulgaria to 60,495 EUR in Denmark, bearing proportion of 1 to 10.4 (Table 6). Annual employee earnings in Croatia were 13,007 EUR, which is 2.6 times lower than the EU-28 average annual earnings and which ranks it in the group of EU countries with a low level of earnings. If we analyse the median gross hourly earnings in 2016 (Eurostat 2016), the position of Croatia is even worse as Croatian employees earn only 10 EUR hourly, which is 4.3 times less than in Denmark, and 3 times less than gross hourly earnings in EU28 countries. Only Bulgaria (4.4 EUR), Romania (5.5 EUR) (Chivu, Ciutacu \& Georgescu, 2015), Latvia (7.5 EUR), Lithuania (8 EUR) and Poland (8.4 EUR) have lower gross hourly earnings than Croatia. Ireland, which has been attracting increasing numbers of young people from Croatia, has almost three times higher gross hourly earnings (29.3 EUR) and 3.7 times higher average annual earnings than Croatia. Germany, which is a traditional destination for immigrants who are leaving Croatia in search of a better life, holds a similar promise: the average annual earnings are 3.5 times higher than in Croatia while the median gross hourly earnings are 33.4 EUR.

Table 6 Structure of earnings survey: annual earnings

\begin{tabular}{l|l|l|l|l}
\multicolumn{5}{c}{ (EUR) } \\
\hline GEO/TIME & $\mathbf{2 0 0 2}$ & $\mathbf{2 0 0 6}$ & $\mathbf{2 0 1 0}$ & $\mathbf{2 0 1 4}$ \\
\hline $\begin{array}{l}\text { European } \\
\text { Union (current) }\end{array}$ & $:$ & 29.506 & 31.176 & 34.210 \\
\hline
\end{tabular}

\begin{tabular}{|c|c|c|c|c|}
\hline $\begin{array}{l}\text { Euro area (19 } \\
\text { countries) }\end{array}$ & $:$ & $:$ & 34.513 & 37.967 \\
\hline $\begin{array}{l}\text { Euro area (18 } \\
\text { countries) }\end{array}$ & $:$ & 31.697 & 34.841 & 38.337 \\
\hline Belgium & : & 38.125 & 45.280 & 47.527 \\
\hline Bulgaria & 1.862 & 2.606 & 4.686 & 5.814 \\
\hline $\begin{array}{l}\text { Czech } \\
\text { Republic }\end{array}$ & 7.174 & 9.781 & 12.696 & 12.542 \\
\hline Denmark & : & 47.637 & 56.083 & 60.495 \\
\hline Germany & : & 39.396 & 41.495 & 45.429 \\
\hline Estonia & : & 8.148 & 10.585 & 13.609 \\
\hline Ireland & 35.450 & 42.876 & 44.146 & 48.598 \\
\hline Greece & $:$ & 26.933 & 26.106 & 22.957 \\
\hline Spain & 21.792 & 24.262 & 27.975 & 28.933 \\
\hline France & : & 32.493 & 34.927 & 37.253 \\
\hline Croatia & : & $:$ & 12.402 & 13.007 \\
\hline Italy & : & 30.560 & 32.751 & 36.242 \\
\hline Cyprus & : & 24.486 & 27.344 & 25.670 \\
\hline Latvia & : & 5.839 & 8.526 & 10.195 \\
\hline Lithuania & 4.099 & 5.716 & 7.226 & 8.756 \\
\hline Luxembourg & : & 47.016 & 51.643 & 58.797 \\
\hline Hungary & 5.873 & 8.115 & 9.879 & 10.209 \\
\hline Malta & $:$ & 17.654 & 19.600 & 22.641 \\
\hline Netherlands & 37.003 & 38.998 & 44.965 & 49.756 \\
\hline Austria & $:$ & 37.049 & 40.514 & 44.454 \\
\hline Poland & 6.878 & 8.574 & 10.507 & 11.665 \\
\hline Portugal & $:$ & 16.597 & 18.507 & 17.497 \\
\hline Romania & 2.344 & 4.223 & 6.031 & 6.746 \\
\hline Slovenia & 12.560 & 15.809 & 21.162 & 22.508 \\
\hline Slovakia & 5.506 & 6.771 & 10.321 & 12.265 \\
\hline Finland & : & 34.345 & 39.635 & 44.543 \\
\hline Sweden & 31.388 & 34.197 & 38.981 & 44.845 \\
\hline $\begin{array}{l}\text { United } \\
\text { Kingdom }\end{array}$ & 41.102 & 44.377 & 38.470 & 42.037 \\
\hline Iceland & : & $:$ & 32.551 & 44.188 \\
\hline Norway & : & 50.440 & 58.075 & 63.157 \\
\hline Switzerland & : & $:$ & 68.488 & 75.886 \\
\hline Montenegro & : & : & $:$ & 8.778 \\
\hline $\begin{array}{l}\text { Former Yug. } \\
\text { Rep. of } \\
\text { Macedonia }\end{array}$ & : & : & 5.824 & 6.599 \\
\hline Serbia & : & $:$ & $:$ & 7.008 \\
\hline Turkey & : & 8.405 & 10.386 & 10.341 \\
\hline
\end{tabular}

For the comparative analyses of individual and group incentives and benefits between Croatia and European and non-European countries we used the data published by CRANET survey on comparative human resource management International Executive Report 2017. "Cranet" is an international network of business schools which regularly conducts a survey of Human Resource 
management, enquiring into policies and practices in people management through a set of common questions. The survey is undertaken approximately every five years and this report for 2017 discusses the Cranet survey data collected between 2014 and 2016.

As shown in Table 7, the differences in application of individual and group financial and non-financial incentives are not as great as the differences in salaries. CRANET research allows us to compare the structure of earnings between employees in Croatia, employees in EU countries, non-EU European countries (Norway, Russia, Switzerland and Turkey) and non-European countries (Australia, Brazil, China, Cyprus, Iceland, Indonesia, Israel, the Philippines, Russia, South Africa and USA). Since share plan and options are rarely applied in Croatian enterprises, the biggest differences can be found in this area. It is interesting to note that share plan is used by $15 \%$ to $18 \%$ enterprises in European and non-European countries while only $7.1 \%$ of Croatian enterprises have included share plan in their compensation package. As regards stock options, a group incentive which is somewhat less popular in Europe than share plans, Croatia compares even better: $7.1 \%$ is half-way to achieving the EU average. Profit sharing is the most widely applied group incentives according to CRANET data, and Croatia is no exception. Profit sharing is used in $21 \%$ of the sampled Croatian enterprises, which means that Croatia lags behind the EU average by only $5 \%$.

Performance related pay is the most frequently used form of individual incentives in Croatia. It is applied by $54 \%$ of enterprises, which comes quite close to the EU average of $58 \%$. Next, nonmonetary incentives are applied by about $50 \%$ of enterprises in all European and non-European countries, meaning that the application of individual non-monetary incentives (38\%) and group non-monetary incentives (32\%) in Croatia (where $52 \%$ of enterprises use at least one of them) is entirely comparable with the practices in other countries.

Table 7 Comparative analysis of incentive pay between Croatia and other countries (\% of sampled enterprises)

\begin{tabular}{l|c|c|c|c|c}
\hline \multirow{2}{*}{ Countries } & \multicolumn{2}{|l|}{ Group Participation } & $\begin{array}{c}\text { Stock } \\
\text { options }\end{array}$ & $\begin{array}{c}\text { Performance related } \\
\text { pay }\end{array}$ & $\begin{array}{c}\text { Non-monetary } \\
\text { incentives }\end{array}$ \\
\cline { 2 - 6 } & Share plan & Profit sharing & 14 & 58 & 50 \\
\hline EU & 17 & 26 & 11 & 65 & 51 \\
\hline Non EU Europe & 15 & 27 & 15 & 59 & 52 \\
\hline Non-Europe & 18 & 31 & 7 & 54 & 52 \\
\hline Croatia & 7 & 21 & & & \\
\hline
\end{tabular}

Next we explored the application of nonmandatory benefits in Croatian and EU enterprises because they have a significant role in attracting and retaining employees. A comparative analysis of some important benefits is shown in table 8 .

Workplace childcare is of vital importance for working mothers and can significantly contribute to quality of life. This benefit is available to about $10 \%$ of employees in European and non-European countries while only $5 \%$ of working parents in Croatia have this option. Private health care schemes are provided by only $27 \%$ of Croatian enterprises, which makes this option twice as rare as in other European and non-European countries. The probable reason for this discrepancy could be found in the fact that health insurance is a mandatory benefit in Croatia and workers, consequently, do not assign too much importance to this voluntary benefit. It is possible to take a break for education and training purposes in 57\% of Croatian enterprises, which is very similar to the situation in European countries and 19\% more than in non-European countries. At the same time (see Table 5), $43 \%$ of Croatian enterprises provide paid seminars and conferences to everybody in the company while this option is available only to specific groups of employees in $52 \%$ of Croatian enterprises. Additional pension insurance is possible in $30 \%$ of Croatian enterprises, which is very close to the average of $36 \%$ in non-European countries, but $19 \%$ less than in the EU countries. This additional benefit is very important for employees in Croatian enterprises because the level of mandatory pensions is quite low and additional pension insurance may help to improve the quality of life after retirement. 
Table 8 Comparative analysis of some important nonmandatory benefits (\% of sampled enterprises)

\begin{tabular}{|c|c|c|c|c|c|}
\hline 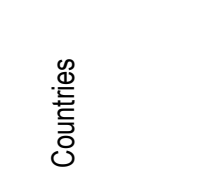 & 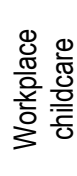 & 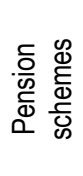 & 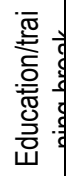 & 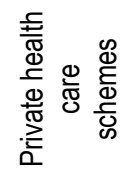 & 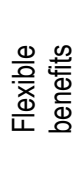 \\
\hline EU & 9 & 49 & 53 & 47 & 37 \\
\hline $\begin{array}{ll}\text { Non } & \text { EU } \\
\text { Europe } & \\
\end{array}$ & 10 & 55 & 61 & 49 & 31 \\
\hline Non-Europe & 11 & 36 & 38 & 49 & 37 \\
\hline Croatia & 5 & 30 & 57 & 27 & 12 \\
\hline
\end{tabular}

The largest difference between the EU countries and Croatia lies in the availability of flexible benefits. Only $12 \%$ of Croatian enterprises enable their employees to choose a flexible benefits package and this is 3 times less than in the EU countries, where this option is available to employees in $37 \%$ of the sampled enterprises.

\section{Research limitations}

Some research limitations must be mentioned. The sample consists of only 61 companies and, consequently, representativeness might be lower than was initially aimed for. The questionnaire was filled out by HR managers only, which implies response bias. Certain steps were taken in order to minimize the effects of single-method bias: respondents were guaranteed anonymity to increase the accuracy of the responses; control questions were placed in different sections of the questionnaire; the expertise of our respondents was unquestionable, as they were members of the corporate HR team. Comparative analysis of reward strategy and practice between Croatia and the EU countries uses data from two different research studies, which can diminish the accuracy of the data obtained through comparison.

\section{Discussion and conclusion}

The purpose of this paper was to perform a critical evaluation of compensation strategies and practices used by Croatian enterprises with respect to EU practices, and to support the analysis with some empirical data. We showed that there is a very clear gap in the EUR annual earnings of Croatian employees as compared to the average annual earnings for the EU countries. Earnings differences, as shown in Table 7, can be a potential drawback for countries that offer below average earnings since this might cause brain drain to high earning countries. Fifteen years ago, Kressler
(2003) argued that the significant differences in the level of reward that exist between individual countries would gradually be levelled out as a consequence of growing mobility in a shrinking economic world, and that is already occurring, not only as regards senior management positions but also with employees of all education levels and types of specialization.

Since the EU promotes workforce mobility, such statistics can be a sign of threat for Croatian companies. Net migration flow with other countries is already showing negative results. According to the Croatian Bureau of Statistics (2017), the number of inhabitants in all Croatian counties has decreased by 10 to $15.7 \%$ over the last ten years (2007 - 2017), except in the cities of Zagreb and Zadar, Istria and the DubrovnikNeretva County. Given that this outward mobility trend mostly involves younger people and that fewer and fewer children are being born, the population in Croatia is getting older and older. For instance, the average population age in Croatia increased from 40.8 years in 2007 to as much as 43.1 in 2017.

It is obvious that total annual earnings depend indirectly upon numerous factors determined on the macroeconomic level, and are not solely under firm control. However, even in the situation of limited financial resources compensation strategies and practices should be optimized in a way to ensure employee satisfaction. Not only the earnings level, but also the structure of pay is important for the satisfaction of employees. Table 8 shows that the differences in incentive pay practices between Croatia and other countries are not so great. Performance-related pay is the most frequently used individual incentive both in Croatia and in all other EU and non-European countries. When talking about Central and Eastern European (CEE) countries, the situation is very similar. According to Berber et al. survey (2017) financial participation for managers is used less (employees share schemes are used in $16 \%$ of all organizations, profit sharing in $21 \%$ and stock options in $10 \%$ ) than performance-related pay. Non-monetary incentives are applied as frequently in Croatian enterprises as in other EU and nonEuropean countries.

Next, many benefits are frequently provided universally, such as paid commuting expenses, social activities, education and training, discounts on company products and similar, but some of them are mostly related to employee status: e.g. company car, paid seminars and conferences, and 
flexible working hours. Our comparative analysis of some important benefits between Croatia and European and non-European countries shows that workplace childcare, flexible benefits, private health care schemes and additional pension schemes are used rather more infrequently in Croatian enterprises than in other countries. This gap opens an opportunity for Croatian enterprises to increase the attractiveness of their compensation strategy and practice.

Consequently, what should be done to improve the compensation strategy and practice of Croatian enterprises and to make them more attractive for young people who are considering leaving Croatia? The large gap between the annual earnings in Croatia and the EU countries is the most serious problem and it is one of the most frequent reasons for emigration to countries with a higher standard of living. The only way to somehow counteract this trend and reduce emigration is to increase the low annual earnings level of Croatian employees and the state tax policy must support this process by lowering the taxes connected with employee earnings. The employers have a very important role in this process as well: they should try to pay their employees above market average because it is the only way to keep the best talents and specialists. Performance-related pay schemes should be applied by even more employers as they are a strong incentive for the best talent. This approach also includes bonuses based on individual and team goals as a very popular tool to increase employees' engagement and efficiency. The usage of share plans and stock options could also be greatly enhanced, especially with respect to managers and specialists. Profit sharing encourages loyalty to the firm and should be applied to all employees in the enterprise. When talking about non-monetary benefits, workplace childcare is very important for young families and mothers because it enables them to concentrate on the work and makes their every-day life much easier. Flexible benefits are very popular in the EU and USA because they enable everybody to satisfy their personal needs and priorities. A greater use of flexible benefit packages can increase employee's satisfaction and make the enterprise more attractive at the labour market. Finally, work-life balance is especially important for young people and employers should try to fulfil their expectations and invest more effort into learning about young people's wishes through regular communication. As well they must know that the factors influencing job search are related to employer branding, employer's position and employer attractiveness on labour market (Bejtkovský, 2018).

To introduce these changes it is necessary for the organizations to develop corporate cultures that promote openness and tendency for changes. According to Adamik, Nowicki \& Szymanska (2018) "openness is an expression of an enterprise's ability to adapt to changing environment conditions and its ability to cooperate with different types of partners. A given company's openness shows its readiness for the creation of dynamics of many business processes", including the creation of competitive compensation policy. To achieve this goal human resource managers and knowledge workers must have skills and understanding of the possible ways to navigate through and adapt to constant change (Tsui \& Dragicevic, 2018).

\section{Acknowledgement}

This paper has been sponsored by Croatian Science Foundation.sm

\section{References}

Armstrong, M., Stephens T. (2005). Employee Reward Management and Practice. London: Kogan Page https://doi.org/10.1177/103841119303100214

Armstrong, M. (2012). Armstrong's Handbook of Reward Management Practice (4th ed.). London: Kogan Page. https://doi.org/10.1108/00197850910983965

Armstrong, M. (2015). Armstrong's Handbook of Reward Management Practice. (5th ed.). London: Kogan Page. https://doi.org/10.1108/00197850910983965

Adamik, A., Nowicki, M., \& Szymanska, K. (2018). Openness to co-creation as a method of reducing the complexity of the environment and dynamizing companies' competitive advantages. Management \& Marketing - Challenges for the Knowledge Society, 13 (2), 880-896. https://doi.org/10.2478/mmcks-2018-0011

Bashker, D.B. (2013). Compensation and Benefit Design. USA: FT Press - Person Education LTD https://doi.org/10.1177/088636878501700206

Bejtkovský, J., (2018). Factors influencing the job search and job selection in students of Generation $Y$ in the Czech Republic in the employer branding context. Management \& Marketing - Challenges for the Knowledge Society, 13 (3), 1133-1149. https://doi.org/10.2478/mmcks-2018-0028

Berber, N., Morley, M. J., Slavić, A., \& Poór, J. (2017). Management compensation systems in Central and Eastern Europe: a comparative analysis. The International Journal of Human Resource Management, 28 (12), 1661-1689. https://doi.org/10.1080/09585192.2016.1277364

Chivu, L., Ciutacu, C., \& Georgescu, L. (2015). Household income in Romania. A challenge to economic and social cohesion. Procedia Economics and Finance, 22, 398401. https://doi.org/10.1016/S2212-5671(15)00310-X 
CRANET (2017). Survey on comparative human resource management - International Executive Report.

Dohmen, T., Falk, A. (2011). Performance pay and multidimensional sorting: Productivity, preferences, and gender. American Economic Review, 101, 556-590. https://doi.org/10.1257/aer.101.2.556

Eurostat (2020). Structure of earnings survey: annual earnings. Retrieved January 15, 2020, from http://appsso.eurostat.ec.europa.eu/nui/show.do?datas et=earn_ses_annual\&lang=en

Galetic, L. (2015). Kompenzacijski menadžment. Zagreb: Sinergija

Green, C., Heywood, J. (2008). Does Performance Pay Increase Job Satisfaction? Economica, 75, 710-728. https://doi.org/10.1111/j.1468-0335.2007.00649.x

Gross, S. E., Friedman, H. M. (2004). Creating an Effective Total Reward Strategy: Holistic Approach Better Supports Business Success. Benefits Quarterly, 20 (3), 7-12. https://doi.org/10.1142/9781783269938 0004

Hansen, D. G. (1997). Worker performance and group incentives: A case study. Industrial and Labor Relations Review, 51 (1), 37-49. https://doi.org/10.2307/2525033

Henderson, R.I. (2006). Compensation Management in a Knowledge-Based World (10th ed.). New Jersey: Pearson Education,Inc. https://doi.org/10.2139/ssrn.763325

Jenkins, D. G. et al. (1998). Are financial incentives related to performance? A meta analytic review of empirical research. Journal of Applied Psychology, 83 (5), 777 78. https://doi.org/10.1037/0021-9010.83.5.777

Jovanović, M. (2019). The political behavior of managers and employers as an instrument for advancing career influence and factors on individual and organizational effectiveness. Ekonomika 65, (4), 87-105.

Kottey, B., Sheridan, A. (2004). Changing HRM practices with firm growth. Journal of Small Business and Enterprise Development, 11 (4), 474-486. https://doi.org/10.1108/14626000410567125

Kressler, H. W. (2003). Motivate and Reward. Palgrave Macmillan https://doi.org/10.1057/9781403937711

Martocchio, J. J. (2006). Strategic Compensation: A Human Resource Management Approach (4th ed.). New

\section{$\checkmark$ Correspondence}

\section{Lovorka Galetić}

University of Zagreb, Faculty of Economics \& Business,

Zagreb, Croatia

Trg John F. Kennedy 6, 10000, Zagreb,

Croatia

E-mail: Igaletic@efzg.hr
Jersey: Prentice Hall

https://doi.org/10.1016/s1053-4822(03)00014-7

Milkovich G., Newman J., Gerhart B. (2014). Compensation. New York: McGraw-Hill/Irwin

O'Halloran, P. L. (2012). Performance pay and employee turnover. Journal of Economic Studies, 39 (6), 653-674. https://doi.org/10.1108/01443581211274601

Renaud, S., Morrin, L. (2015.) Traditional VS innovative benefits: A longitudinal test of their differential impact on Canadian ICT workers' turnover. Paper presented at the Reward Management Conference, Bruxelles, Belgium, EIASM https://doi.org/10.1027/1866-5888/a000180

Schraeder, M.,Becton, J.B. (2003). An Overview of Recent Trends on Incentive pay Program. The Coastal Business Journal, 2 (1), 18-27.

Shields J. (2008). Managing Employee Performance and Reward. Melbourne: Cambridge University Press https://doi.org/10.1017/cbo9781139168748.017

Shields J. (2016). Managing Employee Performance and Reward (2nd ed.). Melbourne: Cambridge University Press https://doi.org/10.1017/cbo9781139168748.015

Stajkovic, A. D., Luthans, F. (2001.) Differential effects of incentive motivators on work performance. Academy of Management Journal, 44 (3), 580-590 https://doi.org/10.5465/3069372

Tsui, E., \& Dragicevic, N. (2018). Use of scenario development and personal learning environment and networks (PLE\&N) to support curriculum co-creation. Management \& Marketing - Challenges for the Knowledge Society, 13 (2), 848-858. https://doi.org/10.2478/mmcks-2018-0009 